\section{Revue d'ethnoécologie}

$10 \mid 2016$

Inland traditional capture fisheries in the Congo Basin

\title{
Pond fishing in the Congolese cuvette: a story of fishermen, animals, and water spirits
}

La pêche aux étangs dans la cuvette congolaise : une histoire de pêcheurs, d'animaux et d'esprits des eaux

\section{Marion Comptour, Sophie Caillon and Doyle McKey}

\section{OpenEdition}

\section{Journals}

Electronic version

URL: http://journals.openedition.org/ethnoecologie/2795

DOI: $10.4000 /$ ethnoecologie. 2795

ISSN: 2267-2419

\section{Publisher}

Laboratoire Eco-anthropologie et Ethnobiologie

Electronic reference

Marion Comptour, Sophie Caillon and Doyle McKey, «Pond fishing in the Congolese cuvette: a story of fishermen, animals, and water spirits », Revue d'ethnoécologie [Online], 10 | 2016, Online since 31

December 2016, connection on 01 May 2019. URL : http://journals.openedition.org/ ethnoecologie/2795; DOI : 10.4000/ethnoecologie.2795

This text was automatically generated on 1 May 2019.

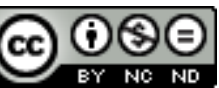

Revue d'ethnoécologie est mis à disposition selon les termes de la licence Creative Commons Attribution - Pas d'Utilisation Commerciale - Pas de Modification 4.0 International. 


\title{
Pond fishing in the Congolese cuvette: a story of fishermen, animals, and water spirits
}

\author{
La pêche aux étangs dans la cuvette congolaise : une histoire de pêcheurs, \\ d'animaux et d'esprits des eaux
}

Marion Comptour, Sophie Caillon and Doyle McKey

\section{Introduction}

1 For hundreds of millions of households in the world, inland fisheries are a primary source of protein and a major source of income (Welcomme 1975, Smith et al. 2005, Welcomme et al. 2010, De Graaf et al. 2015). In the Congo basin, the largest fluvial basin of Africa, fish (along with bush meat) accounts for the bulk of animal protein and are a principal source of cash income for rural households. Fish are sold in both village and urban markets and fishing activities support the employment, directly or indirectly, of many people, including fishermen, traders, vendors, or owners who rent engine canoes (Sautter 1962, Béné et al. 2009, Oishi \& Hagiwara 2015).

2 In seasonal tropical floodplains, shaped by the dynamics of fluctuating water level, fishermen use very diverse fishing methods adapted to seasonality and to the mosaic of microhabitats (Sautter 1962, Van Leynseele 1979, Harms 1989, Welcomme et al. 2010, De Graaf et al. 2015). Some fishing methods are passive, opportunistic, and quite simple to carry out. Others are more sophisticated and require a deep knowledge of the environment, of hydrological patterns and of fish behavior. Fishermen modify habitats to attract fish, making artificial floating prairies and shelters made of piled-up sticks (Harms 1999, Gabriel et al. 2008, Dounias 2011). They also transform the landscape, by constructing dams or fish weirs, in order to catch fish as they migrate (Erickson 2000) or dig ponds to trap fish in these depressions which act as dry-season refugia in the 
floodplain (Toko et al. 2007). Some fishing activities also involve cooperation between humans and animals (Gabriel et al. 2008, Manzi \& Coomes 2010)

Fishing is not just a material practice and a way of meeting protein needs and income sources. Fishing activities are rooted in a complex social, symbolic and ritual construction. In many African societies, waters are inhabited by supernatural forces embodied in different shapes, mostly animals or human-like. Fishermen must deal with these divinities that inhabit the aquatic elements (Fay 1989a, b, Ndinga Mbo 2006, Pagezy 2006, Plancke 2011, Paugy et al. 2015).

In this paper, we will focus on one fishing method in particular, pond fishing, conducted by fishermen in the region of Mossaka, Congo Republic. Pond fishing is a collective fishing method that consists in scooping out water from the pools that remain in the floodplain at the end of the dry season, in order to capture the fish that have sought refuge there. This strategy is widespread in fishermen societies in central Africa. It has been described in the Djoué (Abe'ele Mbanzo'o 2001), Ntumu and Njem (Carrière 2003, Dounias 2011) ethnic groups in Cameroon; in the Ntomba (Pagezy 1989, 2006), Nunu (Harms 1989, 1999) and Libinza (Van Leynseele 1979) ethnic groups in Democratic Republic of Congo (DRC); and in the Mboko and Mbéti (Gami 2002) in the Congo Republic. This collective method is very productive, as it allows capturing a great amount of fish in a short time. Yet, few studies have accurately described the technical, social and symbolic dimension of this activity. Pagezy (1989, 2006), Abe'ele Mbanzo'o (2001), Gami (2002), Carrière (2003) and Dounias (2011) have depicted pond fishing as being conducted exclusively by groups of women and children, during daylight hours. Our findings are more consistent with the descriptions made by Van Leynseele (1979) and Harms $(1989,1999)$, who describe this activity as a process engaging all members of the community.

The purpose of this article is to contribute to the knowledge of this little-studied activity, in a little-studied region. We suggest that this collective fishing method, formerly of great economic importance, may also play an important social and symbolic role. Over the past 50 years, this collective fishing method has declined and more individual fishing methods have increased in importance. In this context, have the social relationships and belief systems linked to this fishery been greatly altered? Do the individual fishing methods that have replaced collective practices such as pond fishing maintain the social and cultural functions of inland fisheries?

6 This study was based on work done during a total of seven months spent in the field over the period from February 2014 to December 2015, in the city of Mossaka, Congo Republic. The first author conducted semi-structured interviews with fishermen, mostly in French. All interviews were tape-recorded and have been entirely transcribed. Our goal was to learn about fishing methods, how fish products are transformed and commercialized, how property rights to fishing grounds are regulated, how fishermen perceive the landscape, and the religious beliefs they hold linked to fishing activities. A diachronic approach was also adopted to assess changes in fishing methods and tenure system over the last fifty years. In total, 62 interviews were conducted with 19 people, ranging from 30 to 70 years in age, about fishing methods. Six persons interviewed were women and 13 were men. Mossaka is a growing, multi-ethnic city, and our informants originated from four different ethnic groups: Likouba, Likouala, Téké and Mbochi. Among them, three people are the heads of their respective lineages, and one is the administrative person in charge of the fishery sector in the district of Mossaka. Although we participated in some fishing activities, we lacked the opportunity to directly observe the pond fishing process. 


\section{The region of Mossaka and its inhabitants in the Congolese cuvette}

7 Located at the junction of the Likouala-Mossaka River, the Sangha River and the Congo River, Mossaka (1 $\left.1^{\circ} 13^{\prime} 27.32^{\prime \prime} \mathrm{S}-16^{\circ} 47^{\prime} 37.84^{\prime \prime} \mathrm{E}\right)$ is the lowest point of the 'Congolese cuvette' (Sautter 1962), which forms the central depression of the Congo basin (Campbell 2005) (Figure 1). The floodplain around Mossaka is characterized by a diversity of microhabitats such as periodically flooded savannahs $\mathbf{s o e}^{2}$, inundated forests poko and ewasa, lakes le bana, channels moliba and pools etongo. Features found along the rivers (bali) include islands esika, sand banks boki, and floating prairies ekoko of the grasses (family Poaceae) Vossia cuspidata and Echinochloa pyramidalis. This landscape is shaped by the seasonal variations in water level. It is mainly the black waters of the Likouala-Mossaka River that submerge the floodplain in the vicinity of Mossaka. This river follows an equatorial, bimodal regime with two high-water periods corresponding to the main (October-December) and the minor (April-June) rainy seasons pela and nzobolo respectively; and two low-water periods corresponding to the major (July-September) and minor (January-March) dry seasons esebo and mwanga respectively (Laraque \& Olivry 1996). In September, waters of the Likouala-Mossaka River rise gradually and, by November, the floodplain is entirely inundated. At low-water seasons, waters recede from the forests and grasslands through numerous channels, revealing a dry floodplain featuring scattered permanent pools and channels (Figure 2).

Figure 1: Mossaka, Congolese cuvette, Congo Republic

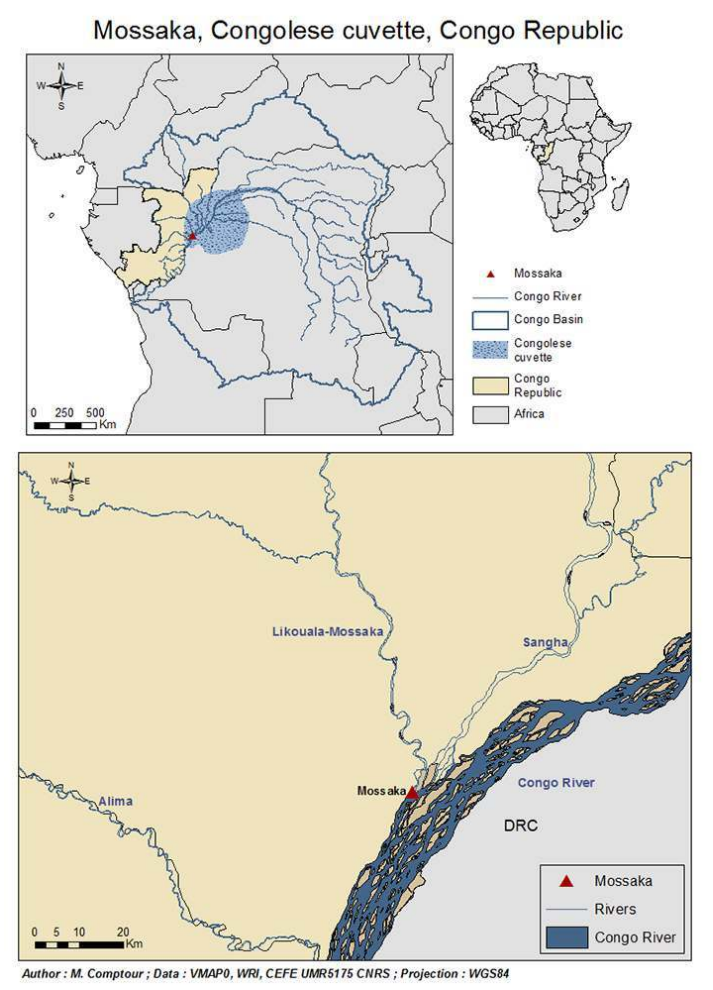


Figure 2: Hydrological pattern of the Likouala-Mossaka River (blue histograms) and rainfall in Mossaka (red line)

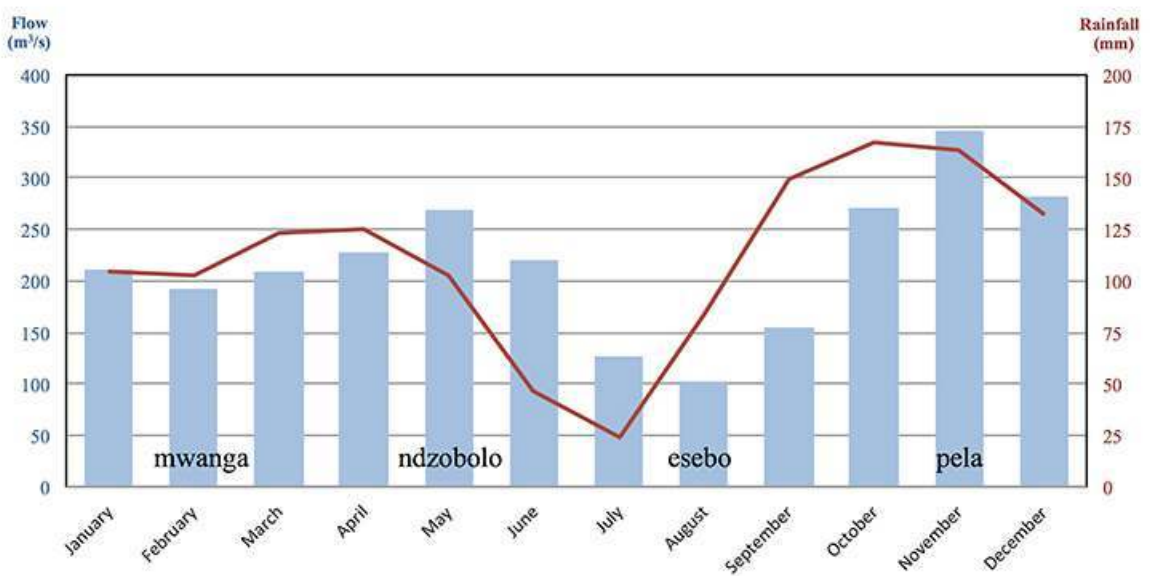

FLow: Mean monthly flow of the Likouala-Mossaka River was calculated over the period 1952-1994, using the data from the hydrological station of Makoua, $220 \mathrm{~km}$ upstream of Mossaka. Source of the data: Laraque A. \& Maziezoula B. 1995.

RAINFALL: Mean monthly rainfall was calculated over the period 1944-2001, using data from the Mossaka station. Source of the data: Agence nationale de l'aviation civile, Brazzaville, Congo Republic.

In this environment, the Likouba ethnic group settled in villages established on the rare naturally raised patches of the floodplain or constructed raised earth mounds to protect their dwellings from the periodic floods (Figure 3). In the past, each village was occupied by one or two lineages owning a territory eboko comprised of inundated forests, rivers, swamps, pools and other features. Still today, lineages own their traditional territories. These territories are inhabited by water spirits bweta, who are considered to be the real owners of the territory and who can control natural resources. Each eboko has its specific bweta (one or more), and the floodplain is thus divided into many lineage territories owned and ruled by distinct water spirits. Lineage territories are traditionally managed by the head of the lineage. In theory, according to the Likouba matrilineal descent system, inheritance of the territory passed from a maternal uncle to his nephew. In practice, the territory could pass from a man to his most worthy (powerful and morally upright) heir (male or female). Over the past fifty years, the inheritance system has shifted towards a patrilineal descent system. The status of lineage head nowadays most frequently passes from a man to his first (or most worthy) son or daughter. The head of the lineage has the responsibility of being the intermediary between the supernatural forces and humans. He enforces the spirits' wishes concerning fishing methods and community rules. 
Figure 3: Raised mounds

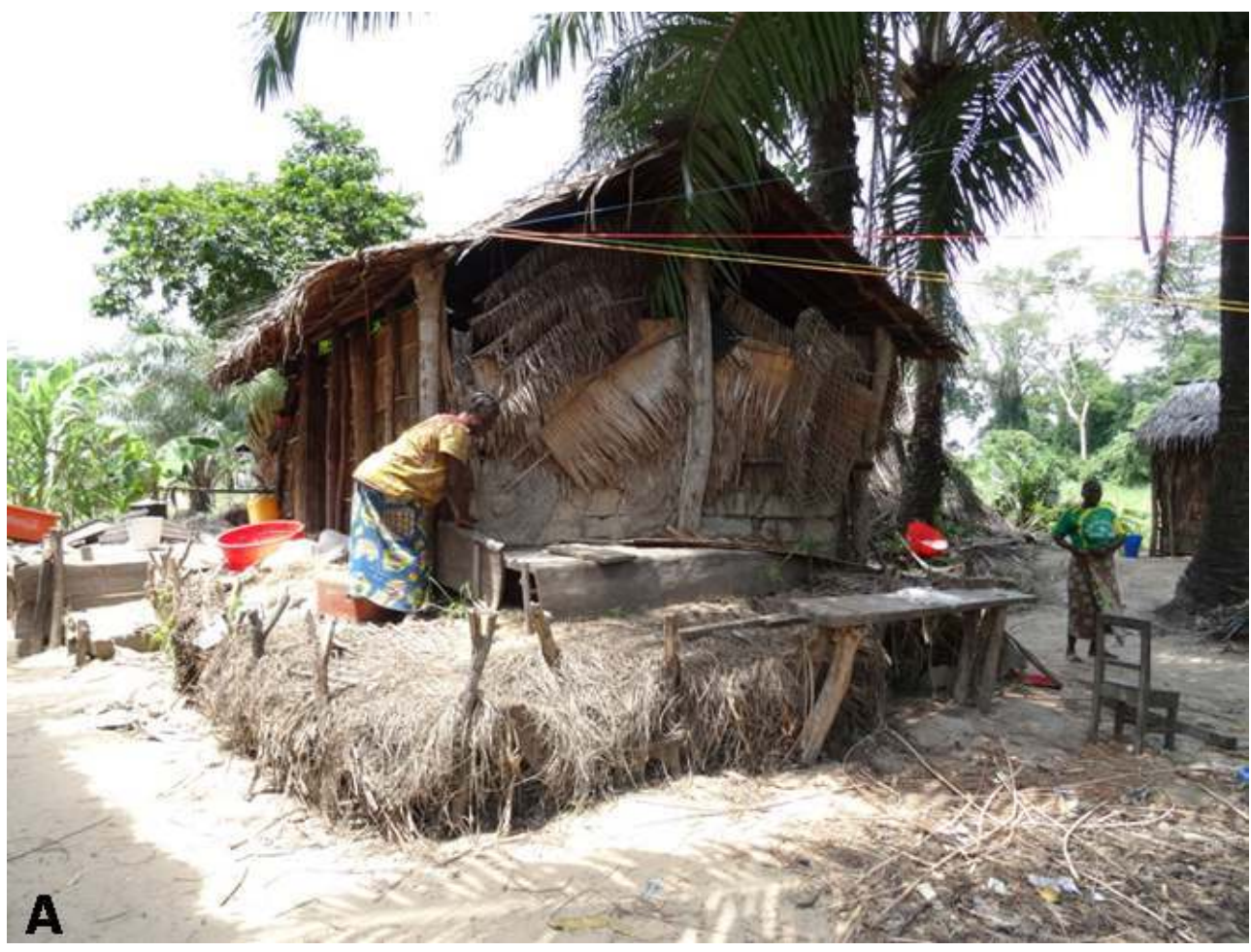

A: In the flood plain, people build earth mounds to protect their dwellings from seasonal flooding (C) M. COMPTOUR

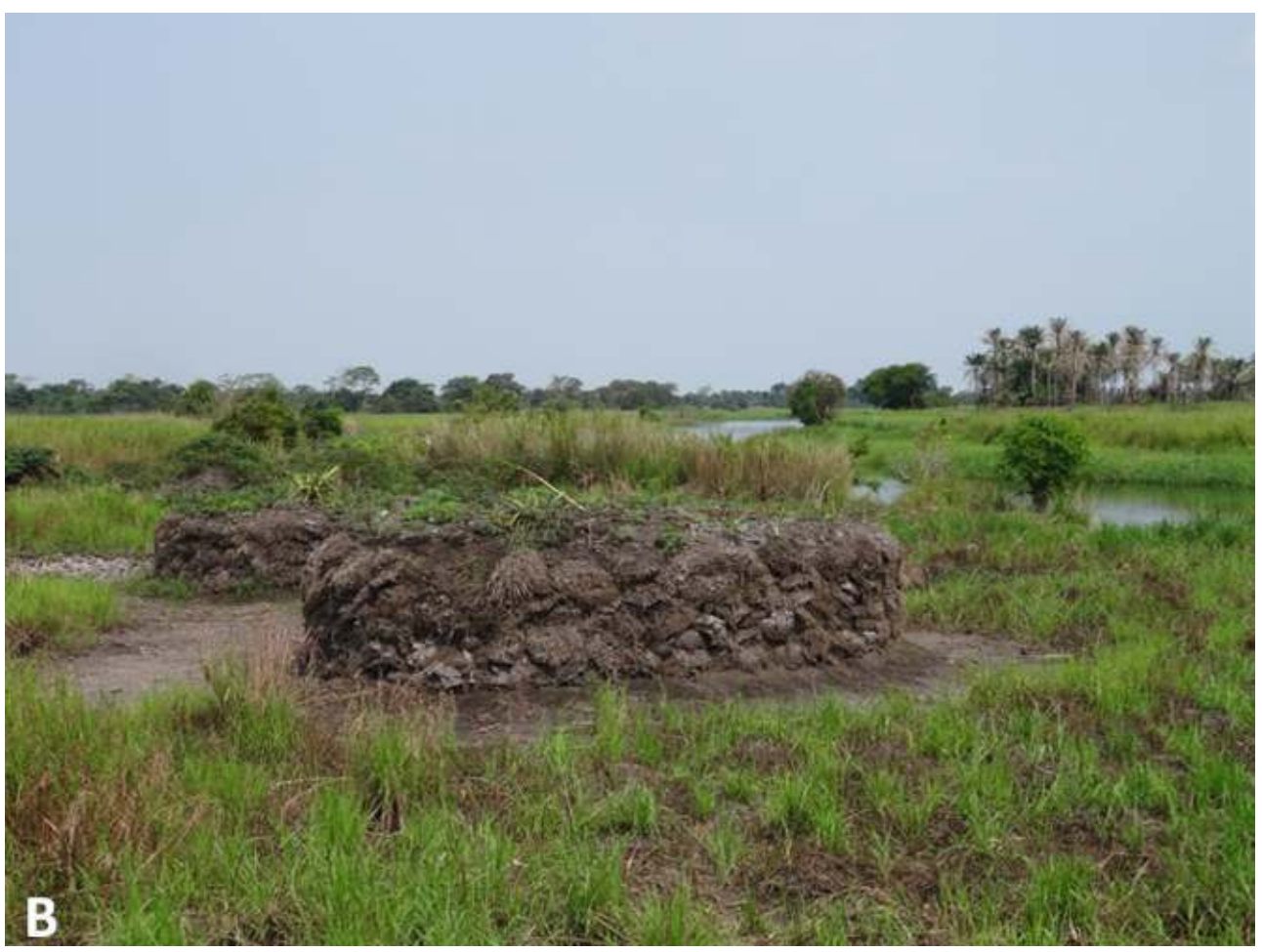

B: Earth mounds are also constructed to serve as agricultural raised fields (C) M. COMPTOUR 
In the region of Mossaka, people rely on varied productive activities such as fishing, trading and growing of crops (primarily cassava). For many households, fishing is the main economic activity. The city and its surrounding region supply a great part of the fish sold in the markets of the capital city Brazzaville (Oishi \& Hagiwara 2015, our observations). At the end of the 19th century, Mossaka was still a fishing camp for Likouba people living in villages in the nearby floodplain. The population of Mossaka has increased considerably due to colonial resettlement policies and to a massive rural exodus over the last fifty years (Sautter 1962). In 2007, 15,000 people of different origins (mostly Likouba, Likouala, Moye [also called Nunu in Democratic Republic of Congo], Bouegni, Mbochi and Téké) inhabited the city of Mossaka (Centre National de la Statistique et des Études Économiques [CNSEE] 2007). The former villages in the floodplain have been almost completely depopulated, transformed into seasonal fishing camps. The diversity of microhabitats and their temporal heterogeneity are reflected in the diversity of fishing methods, among them techniques using hooks, spears, varied kinds of woven basket traps, set gillnets, castnets, driftnets, seine nets, and movable enclosures. In this study, we will focus on pond fishing, a productive and collective fishing method conducted at the end of the dry season in the inundated forests of the floodplain.

\section{Pond fishing}

\section{The practice of pond fishing}

10 As water recedes from the floodplain during the dry season esebo, some fish species will seek refuge in the deepest pools of the inundated forests. These species (which are listed later on in this section) are well adapted to swamp life and to waters with low dissolved oxygen (Welcomme 1975, Chapman \& Chapman 2001, Lévêque 2006). Pond fishing, locally called kopopa ${ }^{3}$, consists in emptying water from these ponds in order to collect fish. In the region of Mossaka, pond fishing is a collective fishing method in which several dozen people (men, women and children) work together. In the Nunu ethnic group living in an area not very distant from Mossaka, in the Congolese cuvette in Democratic Republic of Congo (DRC), Harms (1989: 150-151) reported that "a large pond could require over a hundred people who would work for over a week to empty it".

11 At the end of the major dry season, in August or September, when the water level in the pond is sufficiently low, fishermen will enter the forest to start this fishery. The lineage head will have previously warned all lineage members to get ready and will also have recruited outsiders for the occasion. Outsiders are often people who lack ponds on their own territory, or who, as migrants recently arrived in the floodplain, do not own lineage territories. A stay of a few weeks in the forest is required to empty all ponds and smoke the captured fish. As the main fishing camp is often located near the river, a provisory camp will be built in the forest, at equal distance between the different ponds. Collecting firewood and building racks to smoke the fish that will be captured are among the first tasks to be accomplished upon arrival. Men and women will then renovate and consolidate a dam situated at one edge of the pond. This dam, moboka, will prevent the water from flowing back into the pond once thrown out. Dams are usually made of a fence comprising a double row of wooden sticks bound together with lianas (mbongo), the space between the sticks being filled up with earth, mud, fallen leaves and organic debris. 
Large ponds can be divided into two parts by building a second dam. Women will dig a small channel (mobabale or njabya) or fashion a gently down-sloping surface behind the dam to facilitate the evacuation of water from the pond.

Pond fishing begins after these preparations, at dusk, at about 5 or $6 \mathrm{pm}$ the first day. Fishermen told us they preferred to empty the pond at night, avoiding the heat of the day and working more efficiently. Fishermen divide themselves into three or four groups, each composed of women, men and adolescents. Groups work in shifts, alternating at intervals of two to four hours throughout the night. Standing in the pond, water up to their chests, fishermen drain the pond by scooping out the water over the dam, using finely woven baskets longolo or plastic buckets (Figure 4). This strenuous task is done rhythmically: while half the fishermen dip their baskets into the pond, the other half throw their water out of the pond. During this noisy process, and as the pond gradually dries, some fish will hide in the mud at the bottom of the pond, while most seek refuge in holes situated along the pond bank, often in spaces between tree roots that form a cave beneath the bank. These hollows are locally named mbuku or ndake cu (literally "house of fish") (Figure 5). Once the pond is virtually completely drained, usually by the end of the morning of the following day, fishermen will form a line along the dam and progressively walk towards the banks. While doing so, fishermen catch the fish hidden in the mud by hand or using a machete, then throw them to the banks of the pond, where the youngest children recover them. Other fish are driven into the mbuku. Then comes the most productive, but also the most dangerous, stage of pond fishing, the collection of the hidden fish in mbuku. Several techniques are used to capture the fish that have sought refuge in these holes, which are sometimes a dozen meters deep. If the mbuku is completely dry and not too deep, fishermen use a long stick with a crook at one end to pull fish out into a basket placed at the mouth of the hole. In the technique most frequently employed, however, some of the men, chosen for their courage and skill, will penetrate into the hole armed with machetes, harpoons, and baskets. They will drive fish out of the hole, where other fishermen will pick them up in baskets. This stage is considered to be extremely dangerous, as the mbuku may shelter many snakes, crocodiles (Osteolaemus tetraspis and Mecistops cataphractus), catfish with spines ngolo (Clarias sp.) and electric fish nina (Malapterus electricus). When the hole forms a cave extending into the pond's bank, and is too deep or too barred by obstacles such as tree roots to allow men to get in, several vertical passages can be dug from the top of the cave in order to extract fish with woven baskets from the top. This strategy is also described in Harms (1999: 49): "the fishers would then block the entrance to the cave, dig into it from the top, and take out the fish". 
Figure 4: Scooping out water over the dam

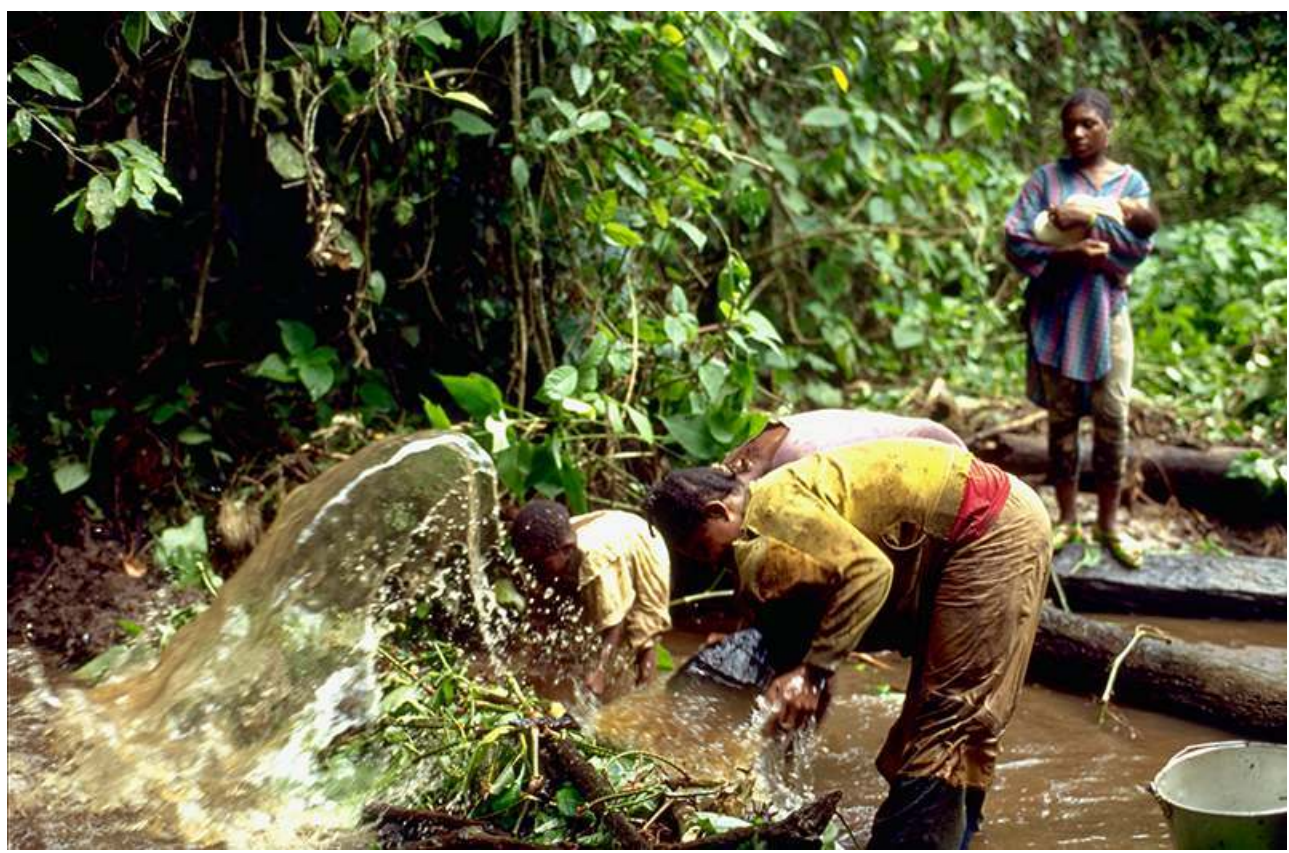

WOMEN OF THE NTUMU ETHNIC GROUP (SOUTHERN CAMEROON) SCOOP OUT WATER FROM A POND TO CAPTURE THE fISH THAT HAVE SOUgHT REFUgE THERE. THIS TECHNIQUE OF HARVESTINg fISH IS ALSO DESCRIBED IN POND fISHINg IN THE REgION OF MOSSAKA.

(c) E. DOUNIAS

Figure 5A: Hole (MBUKU) between tree roots

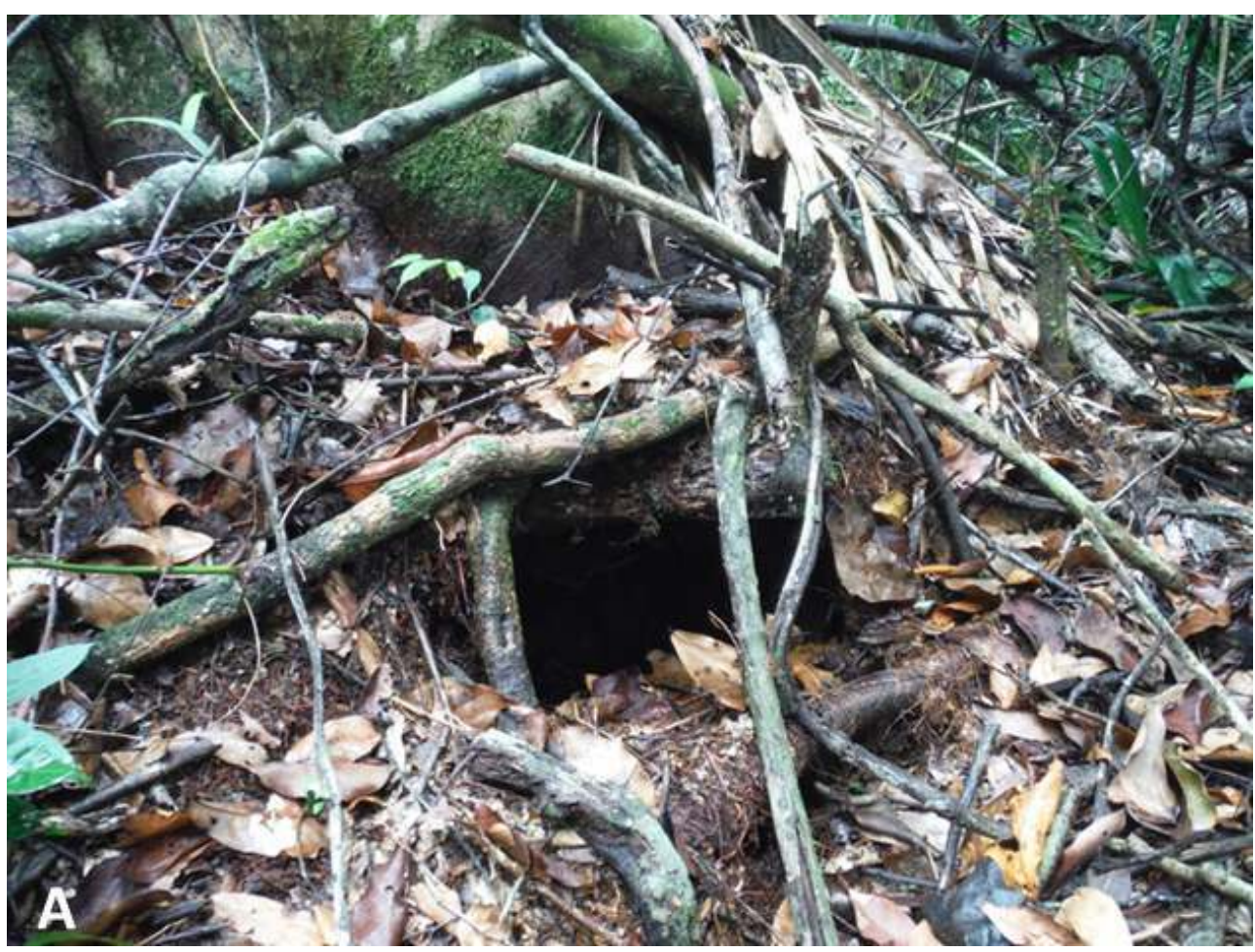

(C) M. COMPTOUR 


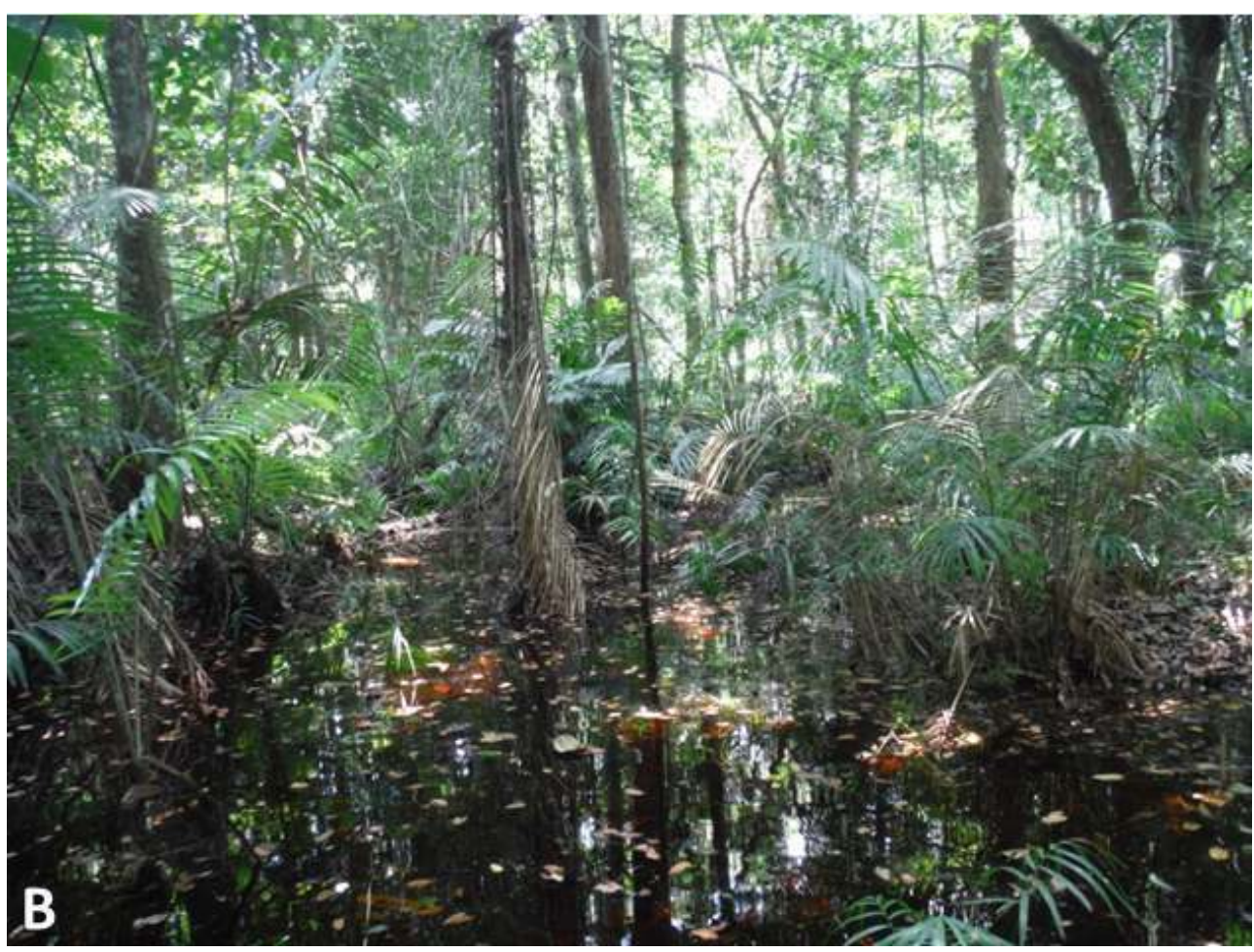

(c) M. COMPTOUR

13 During this study, all our informants stated that pond fishing is done in natural pools within the inundated forests. However, Harms (1999) described the presence of ponds dug by the Nunu fishermen (Congolese cuvette, DRC). We suggest it is likely that ponds can be of both natural and human origin, and that fishermen in Mossaka may have lost some knowledge of a past activity. Still, although the putative anthropogenic origin of some ponds may have been forgotten, fishermen all agree that they shape micro-topography of ponds in order to increase their productivity. The cavities mbuku, where many fish can be caught in a short time, can be of natural origin, caused by tree falls or by burrowing by the crocodilians Osteolaemus tetraspis (ngoki) and Mecistops cataphractus (ngonde) (see the section "human-animal relationships" below). Yet, some ponds lack holes of natural origin, and in others the holes are too small. Fishermen would then have to excavate artificial hollows. One method of doing this consisted in digging a channel about one meter deep and a dozen meters long, then covering it with brushwood and earth in order to constitute a tunnel. Construction of such tunnels was described to us by old fishermen, and is no longer done in Mossaka. Fishermen also increase the attractiveness of ponds to fish by creating hiding places for them: they line the walls of the mbuku with brushwood, and voluntarily leave trunks and tree branches that have fallen into the ponds. Finally, they maintain ponds by removing, every few years, mud, leaves and other organic debris that has accumulated at the bottom of the pond.

14 Fishes caught in ponds are mostly air-breathing fish, adapted to the acidic black waters and anoxic conditions of swamp-forest pools: Clarias spp. (ngolo, lisua, senga ...), Parachanna obscura (tsinga), Polypterus sp. (mokonga), Ctenopoma sp. (molombi), Heterotis niloticus (kongo ya sika), and juveniles of Petrocephalus sp., Mormyrus sp., and Marcusenius sp. (all three species are locally called mbese). Protopterus dolloi (nzombo) is also present 
in ponds but is more difficult to catch, as this species can bury itself deeply in the ground (Lévêque \& Paugy 2006). Among the reptiles, the crocodiles Osteolaemus tetraspis (ngoki) and Mecistops cataphractus (ngonde), the turtles Trionyx triunguis (kumba $\boldsymbol{\varepsilon}$ ndendeke) and Kinixys sp. (kumba), and some snakes (undetermined) are frequently captured to be eaten or sold (Figure 6).

Even though difficult -

"We have to fish all night long, with water up to our chest". (Antoinette, 40-50 yrs) ${ }^{4}$

- and risky, this fishery is very productive and exceeds local needs.

"There are ponds, if you fish there, you will exclaim: "but how can so many fish live here!". Imagine a pond where maybe 50 people can at the end get each 100,000 CFA Francs!" ". (Symphorien, 40-50 yrs)

Figure 6: Some of the fish and reptiles that are caught in ponds

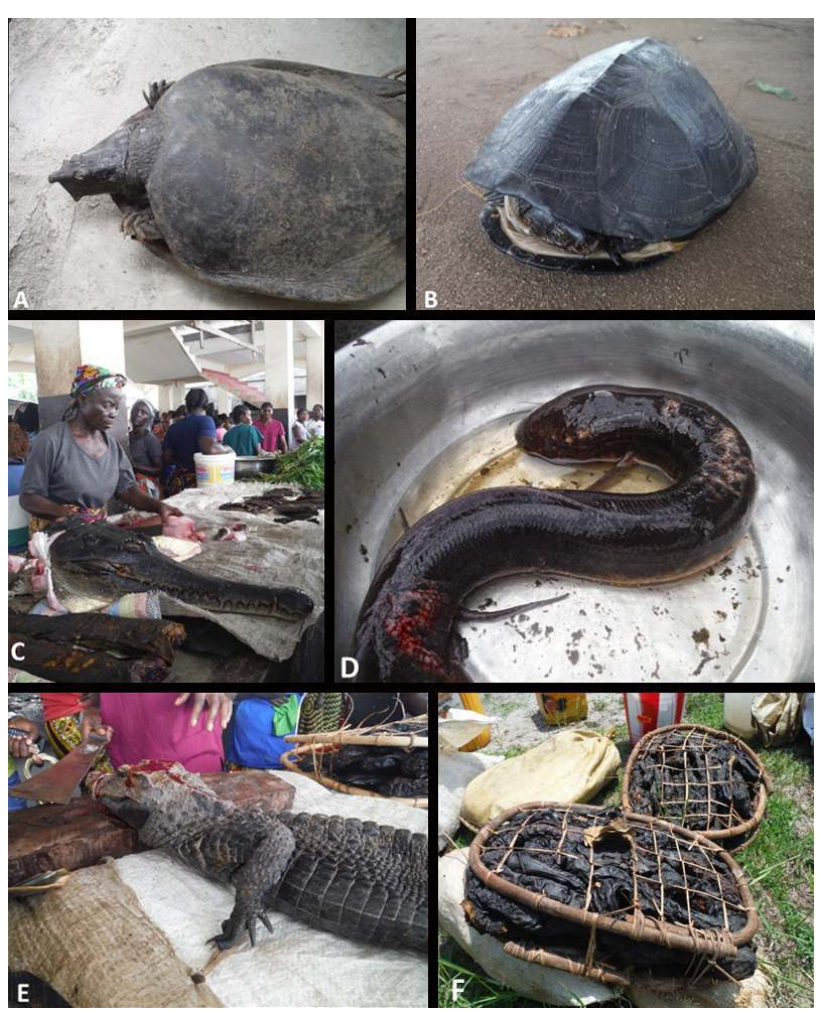

A: Trionyx triunguis (KUMBA ENDENDEKE); B: Kinixys sp. (KUMBA); C: Mecistops cataphractus (Ngonde) sold in the market of Mossaka; D: Protopterus dolloi (NZOMBO); E: Osteolaemus tetraspis (Ngoki); F: Smoked fish (NgoLo) to be sold in markets

(C) M. COMPTOUR

17 A great amount of fish will be sold in local markets or brought to the capital Brazzaville, where the demand is high. Most of the fish to be sold are smoked (mokalu) to keep them from spoiling. Some species (Clarias sp., Protopterus sp., Parachanna obscura), which can be kept alive a few weeks, are preferentially sold alive, at a better price than smoked fish. In this respect, the practice of capturing fish in the mbuku has the added benefit that fish can be seized alive, in contrast to fish in the mud, which are often killed with a machete. Much of the proceeds from selling the fish are used to buy cassava from terra firma areas.

By shaping features of the landscape in order to increase the productivity of pond fishing, people of Mossaka capture a great amount of fish both for self-consumption and to satisfy 
market demand. However, fishing is not only a way to obtain protein and cash. This activity relies on and reinforces social organization, and it is based on a complex and respected system for managing tenure of ponds.

\section{Social organization of pond fishing}

\section{Owners and clients: ponds divide the society}

The floodplain is, as we have seen, divided into many lineage territories eboko, each managed by the lineage head, who is the middleman between the supernatural forces and humans. Access to the lineage territory is not controlled at high water, when fish are spread all over the floodplain. During dry seasons, any lineage member can fish wherever he wants within the territory with hooks lilowo, woven basket traps mokoni and ekyete, or set gillnets tseli, without asking the permission of the lineage head or of the spirit who is the territory's real owner. Yet, some fishing methods and some specific fishing grounds have a more restrictive use and tenure system. In particular, access to the ponds is controlled. Ponds must be fished collectively, at a date announced by the head of the lineage, after he has received, through dreams, the authorization of the water spirit bweta (see the section "human-spirit relationships" below). A person caught fishing on his own in a pond - clandestinely - will be sanctioned, the punishment imposed ranging from a fine to his expulsion from the territory. This land tenure system in Mossaka is consistent with that found in other studies in floodplain fisheries in west Africa, in that tenure regimes are linked to the characteristics of resources: concentrated and stationary resources are more easily defensible than mobile and diffuse resources and access to them is more likely to be restrictive (Fay 1989b, Thomas 1996, Neiland et al. 2000).

Adherence to rules and regulations concerning access and rights is enforced by the head of the lineage. Given his responsibilities, and because he is the heir of the ancestor who discovered or dug the pond and is thus sometimes considered as the "owner of the ponds", the lineage head will take an extra part during the sharing of the catch from pond fishing. The process of sharing the catch was explained to us as follows. At the end of pond fishing, fish captured will be gathered and then distributed in equal parts among all fishermen, both lineage members and outsiders. Youngest children will only get half a part, and pregnant women will have an extra part for the baby to come. Larger parts will be given as a bonus to the brave fishermen who entered the cave in the embankments. In addition to his fisherman's part, the lineage head will take another equivalent part corresponding to the part of the territory, often called "the part of the forest":

"if we are twenty fishermen in total, we will divide the catch in twenty-one equal parts. The head of the lineage will take two parts. If he is not present during the fishing, he will still get his part of the forest". (Fidèle, 50-60 yrs)

It seems, though, that in ancient times the lineage head took a greater part. Indeed, a fisherman stated that

"there are some pond owners who are "greedy", they want to take more. Especially before, owners were really "greedy". They considered people who came to empty the pond as their workers, and at the end they used to take a big part. But now, everyone has an equal part; the fishermen and the owner have an equal part". (Leman, 40-50 yrs) 
In the Nunu ethnic group (DRC), Harms (1989) recorded that the owner of the pond could take all the fish on one side of the smoking racks while the rest were divided equally among the workers, men and women getting equal shares.

As pond fishing is very productive, the selling of the surplus of fish from the different ponds allowed the lineage head to occupy a privileged economic position in the society. Moreover, before the entrance into a monetized system, ponds were used as goods that could be traded. A lineage head could exchange ponds against wives or slaves, increasing in this way his workforce and his power. In cases of conflict between two families (occasioned by theft, adultery or other causes), a pond could also be given to the family judged to be the victim of wrongdoing. In consequence, being a 'pond owner' was a major focus of social competition. As explained previously, there were many possible heirs. Whereas in theory the pond was inherited by the first nephew (in the traditional matrilineal descent system) or first son (in the patrilineal descent system more frequent today), in practice, any member of the lineage (mostly men but also women in some cases), could become manager of a territory. The lineage head must above all be someone powerful, who will be listened to by people, and who has a "good morality" (Fidèle, 50-60 yrs). Many acts of sorcery and intra-lineage conflicts can be traced to competing ambitions to become the lineage head and the owner of ponds. At the scale of the society, whose economy relied in large part on pond fishing, the possession of ponds was a factor of division. Harms (1989) considered Nunu society to include three social ranks: "the owner of the ponds, the members of the pond owner's household, and the households which lacked ponds". Van Leynseele (1979), working among the Libinza, an ethnic group living along the Ngiri River in DRC, also made the distinction between the ponds' owners, who had regular and abundant resources once a year, and the others, who were more vulnerable to variation in available resources. People not owning ponds had two solutions: to work as clients during the collective fishing, or (before the floodplain became densely populated) to migrate into an unsettled region to create a new homestead (Van Leynseele 1979, Harms 1999).

\section{A collective fishing strategy from which all derive some benefit}

The social ranking based on pond ownership must, however, be put into perspective: the lineage head controls access to ponds in his territory and has a larger part of the final catch, but he does not have exclusive fishing rights in ponds. On the contrary, this collective practice requires the participation of many lineage members and of outsiders lacking ponds on their own. Everyone gains some benefit from pond fishing: outsiders, lineage members, men, women, babies to come, children, young, middle-aged, old, strong or less strong, everyone will get a part of the catch. The cupidity of some owners was disapproved of both by society and by the water spirits, who could send bad luck. Moreover, one of the major preoccupations of pond owners was to attract enough clients to empty their ponds. As most ponds in the different lineage territories in the floodplain had to be drained at the same period, there was competition for the workforce. Thus, an owner had to be generous to his clients to maintain their faithfulness through years (Harms 1999).

This collective fishing was also an annual opportunity for people living in different villages to meet up, to create or consolidate friendships and social networks. Although we have no data on this, it is probable that networks of alliances were established during 
these occasions. Nowadays, family members, often dispersed in different villages and urban centers, still come to their lineage territory during the main dry season holidays (from July to September) to fish and to drain the ponds. Former villages, almost empty during the year, come back to life at that time. The lineage head often makes radio calls to alert other clients about the date of pond fishing in his territory.

Thus, in addition to being the basis of the society's economy, pond fishing plays a great social role. In a territory inhabited by spirits and by many animals, pond fishing involves multiple reciprocal interplays between humans and non-humans. It is this set of relationships that will be examined in the following section.

\section{Relationships between humans and non-humans}

\section{Human-animal relationships}

At the end of the main dry season, the lineage head enters regularly into the flooded forest to check the water level in ponds. Birds flying and wheeling over the ponds hunting for fish and amphibians, such as herons mwawa (Ardea sp.), egrets mobobonji ( Egretta sp.), marabous ngombo (Leptoptilos crumenifer), and an unidentified eagle bokwango, are also noted by the lineage head as indicators of the progressive drying of the ponds.

As mentioned before, the holes mbuku extending under the banks can be excavated by the slender-snouted crocodile ngonde (Mecistops cataphractus) and by the African dwarf crocodile ngoki (Osteolaemus tetraspis) (Waitkuwait 1989, Riley \& Huchzermeyer 1999). These burrows are a refuge for these two crocodilian species when waters recede from the floodplain.

"When the ngonde sees a pond, it comes there and it will dig a tunnel, the mbuku.

It catches fish in the pond, and eats them in its tunnel. But the ngonde does not lay its eggs in the tunnel. It lays its eggs on the top of the mbuku, on the ground, not in the tunnel. The ngoki also live in the mbuku. It can dig, but less deeply than the ngonde". (Leman, 40-50 yrs)

"Sometimes there is already a hole, and the ngonde just go there, enlarge the mbuku, clean it up, to live there". (Symphorien, 40-50 yrs)

The two species of crocodiles (M. cataphractus and O. tetraspis) can also dig into the pond to make it deeper. For the fishermen, the presence of a crocodile in a pond indicates that there will be plenty of fish there. The mbuku can also be enlarged by some fish species such as Polypterus sp. (mikonga), Clarias sp. (ngolo, lisua, senga) and Protopterus dolloi ( nzombo) that can dig into the mud. Although ponds may often be initiated by tree falls or excavated by crocodiles, no pond or mbuku is of totally 'natural' origin, because humans usually enlarge the ponds. Likewise, while humans may excavate ponds, no pond is exclusively 'anthropic' in origin. Ponds and mbuku are thus the result of physical processes (e.g., formation of tip-up pools by falling trees) and of co-construction by reptiles and fishermen. Either may initiate ponds, both may enlarge an existing pond and benefit from it.

Birds, crocodiles and humans thus all share the same fishing ground and interact with each other. Fishermen have developed knowledge about the behavior of animals with whom they share the pond. As indicators of water level or as builders of habitat, animals facilitate pond fishing. In this system of relationships, water spirits inhabiting the 
territory also play a great role. How do they interact with animals and humans and influence the practice of pond fishing?

\section{Human-spirit relationships}

\section{An inherited contract}

In the Likouba representations, territories eboko are inhabited by water spirits bweta ${ }^{7}$. As in the lake Tumba region (Pagezy 2006), these spirits are considered to be the real owners of the lineage territory. The bweta live in specific places in the territory, such as a whirlpool, a fast-flowing part of a stream, a meander of a river or a pool in a forest. The name of each bweta is also given to the place he inhabits. The bweta are said to have anthropomorphic traits. They are described as white-skinned people with very long hair. Although they are human-like, the water spirits can also take the shape of animals, most often that of Nile crocodile (Crocodylus niloticus) or of large snakes. In many African ethnic groups, this large crocodile is a central actor of the cosmogony and is adored or feared (Paugy et al. 2015).

Most of the time, water spirits are good and generous. For example, ekembongo, the bweta of Mossaka, guarantees the city well-being:

"Before ${ }^{8}$, there was a river running behind Mossaka. This river was called ekembongo, and the bweta who lives here is also called ekembongo. Ekembongo is the bweta of Mossaka. He lives in a whirlpool, where the ekembongo River flows into the Congo River. Ekembongo swims in the river around Mossaka to visit people, to protect them. It is he who gives fish to people of Mossaka. And the water in the whirlpool is miraculous. If your child is sick, you can go to take water there. You go near the whirlpool, you throw some coins in the water, and then you fill up a water-jar "gargoulette" with water. Then, you have to paddle very fast towards Mossaka. You must not look back. If you do so, ekembongo will take your child away. When your child drinks the water, he will be cured". (Symphorien, 40-50 yrs)

In addition to giving health and protection to the people living in his territory, the bweta also has a nourishing function. On the basis of a contract, the terms and implications of which we will see later, the water spirit allows the members of the lineage to exploit the forest and its aquatic elements, among them fish. The idea that fish and water spirits are closely linked is broadly shared by many water-dependent communities. In Senegal, the water spirit is the 'shepherd' of fish (Paugy et al. 2015). For the Likouba (our study), for the Ntomba living in the Congolese cuvette in DRC (Pagezy 2006) and for the Punu (Plancke 2011) living in an area in the south of Congo Republic, there is a kin relationship between water spirits and fish: the former are considered to be the parents of the latter. The quantity of fish accorded by the spirit will depend on its goodness.

Despite their generous nature, spirits are also feared. The Likouba of Mossaka, like the Ntomba (Pagezy 2006) and the Punu (Plancke 2011), recognize the existence of fundamentally 'bad' water spirits who do not provide a lot of fish and who take pleasure in killing people. Similarly, the 'good' spirits can sometimes send bad luck to the village. If they feel offended, if people have tried to take advantage of them or their gift, if people do not respect the rules of the sacred contract, the spirits will get angry. Water spirits have the power to bring illness, death, and misery to people. They are seen as capricious and unpredictable: "they give to whom they want, when they want and if they feel like it" (Plancke 2011 : 375). 
Fishing activities thus involve multiple interactions between the bweta -the real owner of the territory and parent of the fish-and the fishermen. The bweta allowed the first occupant to fish and hunt in his territory, under the condition that he obeyed certain rules. These rules can concern restrictions on the periods, sites or gears used for fishing. The bweta will also require that the occupant respect moral rules. He particularly condemns robberies, violent acts, and adultery:

"The bweta will tell that we must not fish from that date to that date; or that we must not paddle on that side of the canoe...". (Leman, 40-50 yrs)

"When a fisherman wants to fish in my territory, I first tell him the rules he will have to respect: "you must not steal, you must not take someone else's wife, and you must not drink too much alcohol"'. (Parfait, lineage head, 50-60 yrs)

This right of usage is tacitly renewed from generation to generation and the entire lineage originating from the first ancestor has the right to benefit from it. The contract established between the water spirit and the first ancestor passes on from a man to his nephew or son. The head of the lineage is thus the representative agent of the ancestor, the middleman who mediates between the supernatural forces and humans. Through metaphoric dreams, the bweta dictates his rules and wishes to the lineage head, who will ensure they are followed by all fishermen in the territory. The lineage head also has

"the ability to speak with the spirit". (Symphorien, 40-50 yrs) and

"the bwEta will listen to him". (Leman, 40-50 yrs)

He can ask for the spirit's blessing:

"he goes where the bweta lives and asks to have a lot of fish...". (Symphorien, 40-50 yrs)

If fishermen disrespect the commandments, the lineage head can also ask the bweta to curse the fishing season:

"The head of the lineage can complain about the other fishermen. He can say to the bweta: "there are people here who don't listen to me. I give them rules that they do not respect. I want to feel your strength!" The following day, all fish will be gone. There may have been a big rain, so that fish disappear from the forest; you won't be able to fish in ponds anymore". (Symphorien, 40-50 yrs)

The head of the lineage is thus the 'manager' of the territory who enforces the terms of the contract established between the bweta and the first occupant.

Before beginning pond fishing, a practice that is considered dangerous but that allows people to capture a lot of fish, the head of the lineage will request the particular benevolence of the bweta and will honor him with gifts and celebrations ${ }^{9}$. In the following paragraph, we will detail the relationships between the water spirit and humans during pond fishing.

\section{A trophic relationship}

The bweta often dwells in a large and odd-shaped tree overhanging the pool. The lineage head will go to the tree and ask the spirit the authorization to empty the pond. To gain the spirit's good will, the lineage head offers palm wine camba, kola nuts and distilled alcohol made from cassava and maize toko. Through dreams, the bweta will give his blessing. This process can take several days, as among the Ntomba (Pagezy 2006). If the bweta does not reply to the request, or responds negatively, the fishermen will abstain 
from emptying the pond. The lineage head will afterwards negotiate to ensure the smooth running of pond fishing. He will ask that no one gets hurt and that the rain should not come. Indeed, a rain occurring at the end of the dry season would postpone the date of the emptying of the pond, and can also sometimes cancel this activity. The head of the lineage will also beg for the generosity of the bweta, asking him to provide a lot of fish:

"Before fishing in the ponds, I call the bweta. I tell him "I brought people into the forest; they are not members of our family". I ask him for the fishery to proceed under good conditions, and that no one dies or gets hurt. I ask him to give a lot of fish. Afterwards, I give him camba...". (Parfait, lineage head, 50-60 yrs)

The bweta will thus facilitate pond fishing by regulating climate and by controlling natural resources and fish production. He can also act physically on ponds. Fishermen ascribe to the bweta the ability to take the shape of the Nile crocodile nkoli (Crocodylus niloticus) to dig in ponds in order to increase the ponds' productivity. In contrast to the African dwarf crocodile (O. tetraspis) and the slender-snouted crocodile (M. cataphractus), both of which actually dwell in ponds and excavate burrows, $C$. niloticus is never found in ponds of the swamp forests. It inhabits rivers and lakes and does not venture deeply into the flooded forest (Fergusson 2010).

In exchange for his benevolence and for letting fishermen capture a great amount of fish in the ponds, the water spirit will often ask for a blood price. The bweta will take a life away, causing illness and death of a child (male or female) belonging to the lineage. The victim will often be one of the children of the sister of the head of the lineage, thus from the same lineage in the matrilinear system. The spirit can also decide to take the children of the head of the lineage himself. This blood price is considered as part of the contract established between the ancestor and the water spirit:

"Some bweta ask a price for a good fishery. After the fishery, a child will die. It is because we killed a lot of fish. It's a sacrifice. The bweta offers its protection to the lineage, but he also needs blood!". (Symphorien, 40-50 yrs)

The bweta can also take the shape of the crocodile nkoli (C. niloticus) to kill people and extract the blood price:

"Sacrifices are done in particular places. These places are sacred; you cannot go there alone. For example, in my wife's lineage territory, there is a place called kwali baru. It means "the bones of humans". If you go there, the nkoli will take you from your canoe, and bring you into the water. The following days, we will find your bones lying on the grass. Sacrifices like that happen every year. The crocodile is the spirit that took the form of the crocodile..." ${ }^{10}$. (Symphorien, 40-50 yrs)

Hence, this blood pact is a trophic relationship between the water spirit and humans involving the consumption of fish. Humans eat fish given by the spirit, who will in turn eat ${ }^{11}$ a member of the lineage.

\section{A fertility relationship}

47 It is interesting to note that this trophic relationship between fishermen and water spirits corresponds to an exchange of children. Fishermen will capture fish, which are considered to be the creatures, the children of the bweta. In turn, the bweta will often take a child of the lineage into the spirit world. Hence, the blood pact symbolically impacts the fertility, the regenerative capacity of the lineage (Figure 7). 


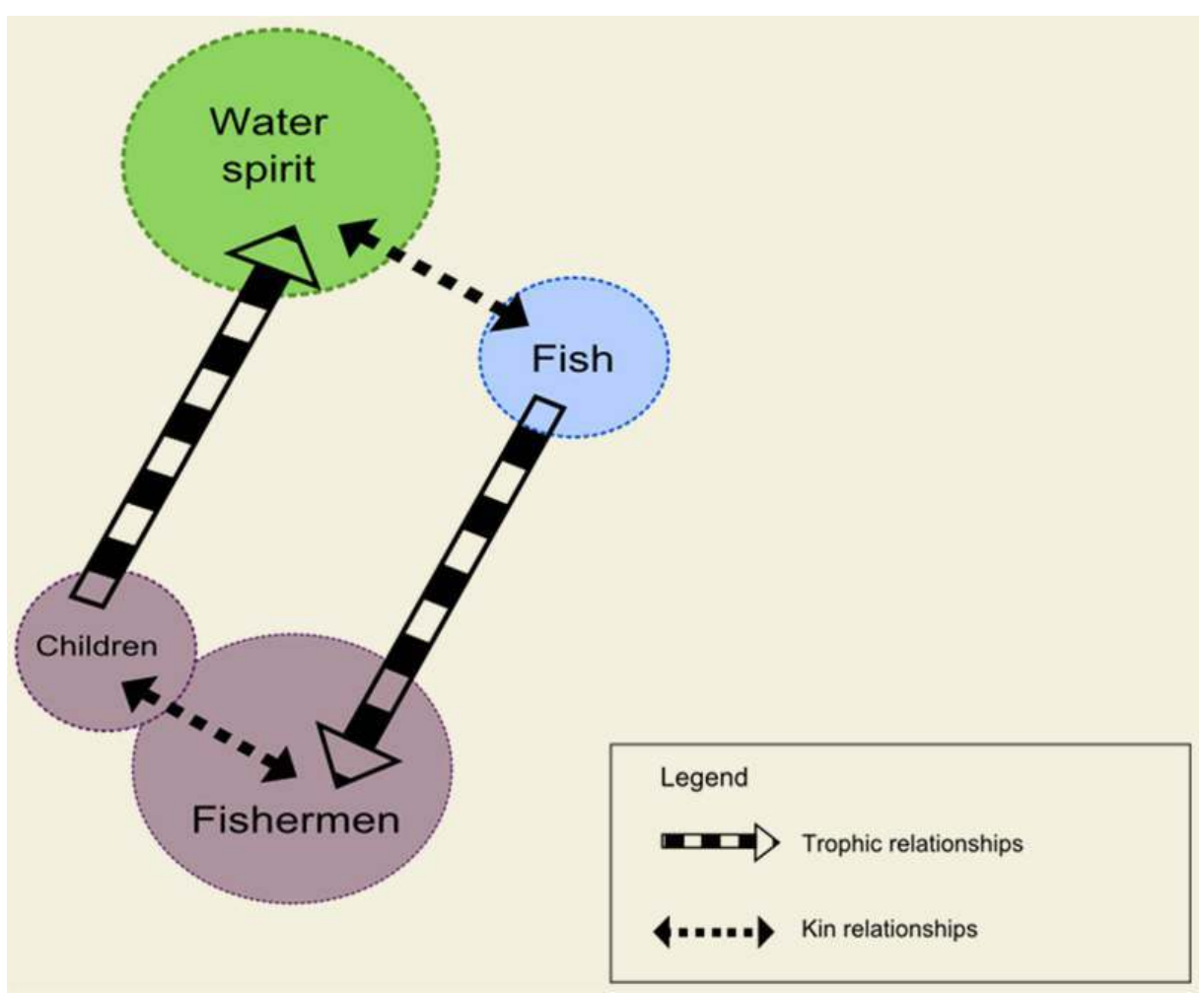

The bweta can take away lives but can also give pregnancy to women. A vision shared by many African societies is that babies come from the aquatic world (where the spirits live) and are a gift to humans from spirits (Pagezy \& Guagliardo 1992, Pagezy 2006, Plancke 2011). Twins, in particular, have a privileged link with the spirit world. They are considered to be spirits who want to live among humans. For the Likouba, twins have supernatural powers and are venerated. In the Punu society, water spirit celebrations are only organized at two occasions: before collective pond fishing and at the birth of twins or the death of one of a pair of twins (Plancke 2011). Pond fishing is symbolic of the fertility relationship that links the spirit world and humans. In the region of Mossaka, this collective fishing is the occasion to honor children, presents from the bweta. Indeed, we have seen that even small children and babies to come will have a portion of the final catch. As pond fishing takes place at the end of the dry season holidays, children will often use the money earned by the selling of the fish to buy school articles and clothes. Plancke (2011) observed among the Punu an analogy between the water spirit world, in ponds, and female fecundity. The 'stagnant and lukewarm waters' of the pond make it resemble a uterus. The pond is the place that shelters plenty of fish and maintains fish life during the dry season when the floodplain is otherwise entirely dry.

In conclusion, in the region of Mossaka, a contract of reciprocity exists between humans and water spirits bweta. The spirits are the owners of the territory and ensure protection, a nourishing function, and the regenerative capacity of the society. Fishermen, whose morality and conduct are constantly supervised, maintain the spirits' favor by means of ceremonies and have to pay a blood price. Pond fishing is particularly symbolic of the trophic and fertility interactions between the spirit and the human worlds. 


\section{A fishing practice in decline} cuvette have been declining (Sautter 1962, Vennetier 1966, Van Leynseele 1979, Harms 1989). In the vicinity of Mossaka, fewer and fewer people are interested in pond fishing. Some people do not know where the ponds of their lineage are located; others fish in these permanent water-filled pools during the dry season using hooks or set gillnets; and generally, knowledge on the origin of ponds and about pond fishing methods is being lost.

51 Many reasons contribute to explaining why fishermen have almost completely abandoned this major collective fishing strategy. With the introduction of individual fishing methods such as hooks and set gillnets in the first half of the 20th century, fishermen began to neglect collective pond fishing, judged too difficult and too socially constraining. Fishermen today notably complain about the obligation to share fish:

"When you fish in ponds, it's as if you are fishing for everyone's advantage, because afterwards we share the fish. Children and people who are not strong also get a part. Even pregnant women will have a part for the baby in their belly... So if you go there alone [without your family], you lose!". (Leman, 40-50 yrs)

'forest part' taken by the head of the lineage is also looked upon with disfavor Fishermen want to extricate themselves from the constraints of lineage membership and the authority of the lineage head. They want to fish on their own, where and when they want. The high market value of fish ${ }^{12}$ and the transition to a cash-based economy add to the attractiveness of these individual fishing methods in economic terms. The abandonment of pond fishing is also linked to the resettlement of villages along the rivers. Ponds, located in the lineage territories of ancient villages in the floodplain, are now quite far from the permanent residences of fishermen. Due to this remoteness and to the difficulty of mobilizing the lineage members to do collective tasks, ponds are not maintained and progressively fill up with silt. As ponds deteriorate and become less productive, they become even less attractive for fishermen. Some fishermen also fear the blood price they will have to give to the water spirit and prefer not to participate in this collective fishery:

"Some people do not like to fish in ponds because of the sacrifices. There are ponds that give a lot of fish, and you know that after pond fishing, someone will disappear...". (Symphorien, 40-50 yrs)

However, these sacrifices are less common nowadays:

"There are places where the ancestors have already made a lot of sacrifices. So now, the spirit no longer asks for a lot of sacrifices...". (Symphorien, $40-50 \mathrm{yrs}$ )

In the floodplain, fishermen now fish mainly on an individual basis with hooks lilowo, set gillnets tseli, or woven basket traps mokoni and ekyete. Individual fisheries have particularly increased in the last fifty years in the main river itself. On the numerous islands of the Congo River, fishing camps have multiplied. Individual fishing methods used in the rivers are mostly castnets yakala, bottom driftnets benda bika, surface driftnets kutepa, and set gillnets, along with woven basket traps and hooks in the floating prairies and along the river banks. In contrast to pond fishing, which relies on landscape transformation and was done every year in the same fishing ground, individual fishing methods require constant mobility of fishermen. In the search for the most 
productive areas, and according to various social factors, fishermen will juggle among many fishing grounds in the floodplain and in the riverbed:

"If after a week in a place you see that you don't get a lot of fish, you change, you go

in another fishing camp, in another river...". (Fidèle, 50-60 yrs)

This mobility relies on access rights based on numerous relationships involving kin, friends, and neighbors. In the lineage territory of the floodplain, all individual fishing gears are used freely by the members of the lineage. Rare are the lineages who accept foreigners in their territory. An outsider willing to fish in the floodplain must first be invited by a member of the lineage and ask permission from the lineage head to fish in his territory. He will then have to pay a fee called monangu (in cash or in an amount of fish) in compensation for the resources taken. The price of the mojangu paid by the outsider often varies according to his degree of familiarity with the lineage head. In consequence, the more a fisherman know people, the more he will get access - at a lower price - to different territories in the floodplain and be able to shift from one to another. In contrast to floodplain fishing grounds that are within lineage territories, the waters of the rivers are freely accessible to all. They particularly allow landless people to get fish without having to give a part away. However, to settle in a fishing camp in the riverbed, a fisherman must also first ask permission to the head of the camp. Thus, although the abandonment of collective fisheries leads to a diminution of the cohesion of the lineage group and to the loss of former alliance networks (Van Leynseele 1979), individual fishing strategies still depend on social relationships to access the territory and the resources.

Fish caught by a fisherman working individually are not shared among the community following institutional rules, as was the case during collective fisheries. However, a fisherman, at the request of his family or other contacts, will often give a part of his catch:

"When you come back from a fishing camp, you can have a lot of fish, a lot of money. But then you will have problems to deal with: your family will ask money, your children, your wife, your relatives in Brazzaville...". (Fidèle, 50-60 yrs)

57 The mojnangu perceived by the head of the lineage, is also, depending on his benevolence, partly redistributed among the lineage members. This money can be used to pay funerals, to cover hospital costs of one family member, or to help someone who needs it. Resources are somehow always redistributed between people.

Becoming the head of the lineage as manager of the territory is not as coveted a position as it formerly was. Despite the potential economic gain (the lineage head receives the outsiders' fee mojangu), some people do not want to assume the responsibilities associated with this status. Indeed, the head of the lineage will have to stay in the fishing camp during the entire fishing season, manage conflicts, and can be the one judged responsible if there is a death in the fishing territory. The neglect of collective fisheries in the floodplain has also led to diminished importance of relationships with the water spirits. The lineage head's function of mediator between the spirits and humans is less valued $^{13}$ : "nowadays, people don't really know how to communicate with the bweta" (Symphorien, 40-50 yrs). However, any fisherman can have potentially access to the spirit world. In order to have more 'luck' - and notably to get more fish - a fisherman can go to a sorcerer who will "give him the power" (Symphorien, 40-50 yrs). In Mossaka, as in most parts of central Africa, sorcery is given as an explanation for someone's unusual luck. In the ideology of sorcery, an increase in one person's richness, health, or happiness, comes at the expense of someone else. A fisherman desiring to increase his catch can go to a 
sorcerer, but this will provoke illness or death of another person. Many studies have shown an increase in the importance of sorcery in central Africa over the last dozen years and have tried to understand the reason(s) for this (Bernault 2005, Henry \& Kadya Tall 2008, Yengo 2008). Without entering into the debate about causes, it seems indeed that the ability to access the spirit world - and ask for success in fishing - is no longer attributed solely to the heads of lineages but is potentially open to any fisherman. Along with the increase of more individual fishing methods, it seems that fishermen are also more autonomous in the 'supernatural' dimension of management of their catch. The diminishing role of the bweta in the fishery does not mean that people no longer believe in bweta. They do, but the function of the bweta in regulating the productivity of the fishery is considered to be less important in a context of more individual economic and mystical practices concerning fishing.

\section{Conclusion} livelihood. They use a broad range of fishing methods adapted to the hydrological pattern and other traits of the habitats they fish in, and to the behavior of the fish species they pursue. Pond fishing is attuned to microtopography and the seasonal migration of fish into and out of the floodplain. At the end of the main dry season, fish that have not returned into the riverbed in time become trapped in depressions within the floodplain, isolated from the hydrographic network, and can then be captured. Unlike many descriptions in other areas of Central Africa, which depict pond fishing as being quite simple and done exclusively by women, among the Likouba, the Nunu (Harms 1989, 1999) and the Libinza (Van Leynseele 1979) ethnic groups in the Congolese cuvette, pond fishing involves the cooperation of large groups of people. It is done collectively by adult men, women and by children belonging to the lineage or to outsiders lacking ponds on their own. Pond fishing in the region of Mossaka is a quite sophisticated technique that relies on observations of the environment and the behavior of animals, on human actions that modify features of the landscape, and on the inherited and constructed local knowledge and skills concerning how best to capture fish during the emptying of the ponds. In these scattered ponds where fish are concentrated, fishermen can harvest a large number of fish in a short time, producing a surplus they can sell. Becoming the owner of ponds was thus in the not-too-distant past a major focus of social competition, yet this collective activity also strengthened social cohesion through collective work.

Pond fishing is a trophic relationship between animals (fish and reptiles that shelter in the pond) and fishermen. As viewed by the Likouba, this relationship is facilitated by the combined action of fish, reptiles, fishermen and spirits, all of which dig and shape features of ponds, increasing by this means the productivity of this fishery. This trophic relationship is permitted by the spirits, who are the real owners of the territory and the parents of fish. This permission relies on a contractual relationship established between the spirits and the ancestor of the lineage. One prescription of this contract implies that, in compensation for giving their children - the fish - to fishermen, spirits will ask for a blood price: they will 'eat' a child of the lineage. In conclusion, pond fishing involves an exchange of trophic relationships between entities linked together by kin relationships. These interactions are mediated by agents of the human and spiritual worlds: the lineage head will receive the proscriptions and prescriptions of the spirits through dreams,

Revue d'ethnoécologie, 10 | 2016 
enforce these rules among the fishermen who fish in his ponds, and can also ask for the benevolence of the spirit. The spirit will take the form of Crocodylus niloticus to kill, but also to help people by digging ponds.

Thus, pond fishing has great economic, social and symbolic importance. It involves multiple relationships among humans, animals and supernatural forces (Figure 8). It is important to consider, however, that these three classes of beings are not closed categories. Indeed, spirits, most often human-like, can take the shape of $C$. niloticus. Humans, notably sorcerers, can also take the form of an animal - crocodile, snake, hippopotamus, or many others - to kill other people. Twins are spirits who live among humans. Fish have a kin relationship with spirits. These findings are consistent with those of other studies conducted worldwide showing that subsistence activities (hunting, fishing, or gathering) have interrelated epistemological (set of knowledge about ecosystems and animal behaviors), practical (expertise, skills, economic relationships) and ethical and perceptual (beliefs, moral and spiritual values) dimensions (Fay 1989a, Fay 1989b, Ingold 2000, Pagezy 2006, Trusler and Johnson 2008, Descola 2011, Reo and Whyte 2012, Shepard 2014). A broadly shared vision is that animals give themselves, or are given by supernatural entities, to hunters and fishermen (Levy-Bruhl 1963; Pagezy 2006; Reo and Whyte 2012). In turn, fishermen and hunters show respect to animals and supernatural entities and follow moral codes and restrictive rules (e.g., concerning access and types of gears that can be used) that are often enforced by a local authority (Fay 1989a, Fay 1989b, Schlager \& Ostrom 1992, Thomas 1996, Sarch 2001, Béné et al. 2003). In some indigenous communities, this gift of resources is paid in turn by a sacrifice, e.g., the death of a small child (Fay 1989b, Pagezy 2006, Shepard 2014).

Figure 8: Relationships among humans, animals and supernatural forces during pond fishing

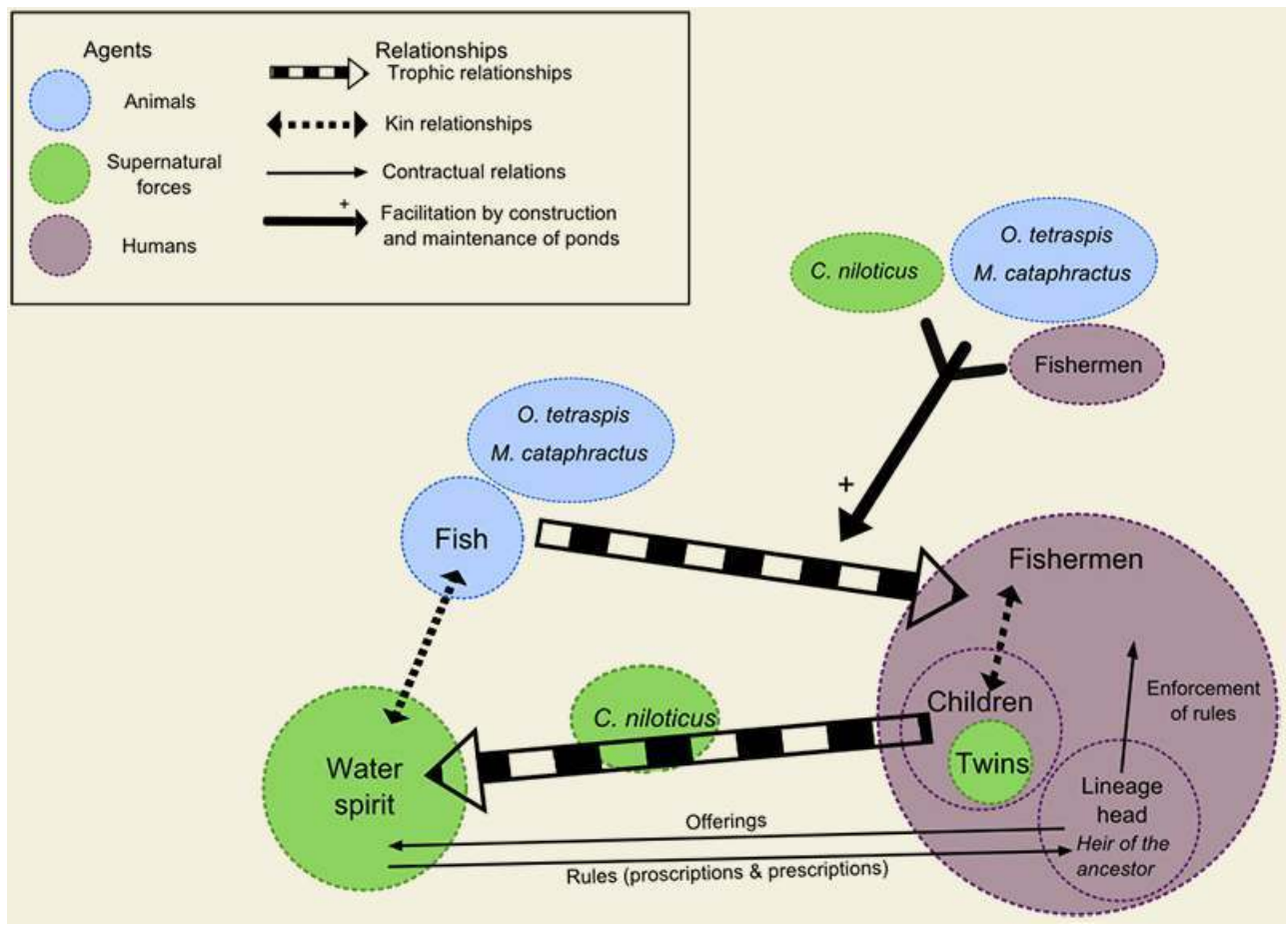

Our study, like these others, raises the question of whether the adoption of new technologies and the passage to a cash economy erode the values and management systems linked to subsistence activities (Reo and Whyte 2012, Shepard 2014). We can also 
ask whether the adoption of more individual fishing methods, or the diminishing function of the lineage head in managing the common pool resource lead to an overexploitation of fish (Ostrom 1990, Schlager \& Ostrom 1992, Béné et al. 2003). In the region of Mossaka, individual fishing methods that have gradually replaced collective fishing methods require great mobility of fishermen, which is only feasible through a rich social network that should be larger than the lineage sphere. Fish caught with individual methods are also redistributed - by the payment of the fee mojangu and by the offering of fish - not only to the lineage of the owner, but also to the rest of the community. The social and economic boundaries of the lineage are faded. The former responsibility of the lineage head to communicate and deal with the spirit world is less acknowledged, but every fisherman can, by sorcery practices, individually influence his own catch. In conclusion, we found that individual fishing methods maintain pre-existing social relationships (in addition to developing new relationships), local knowledge, management systems, and beliefs linked to fisheries. In response to population growth and increased market demand for fish, fishermen in Mossaka have intensified their practices and have noticed a decrease in their catches over the last fifty years. However, the data we have are not sufficient to evaluate the dynamics of fish stocks and their resilience to increasing pressure. We cannot conclude that fish are currently overexploited and that consequently fish resources are declining. We can only note that decreased individual catches result at least partly from the fact that more fishermen are sharing the resource. The role of the traditional authority (often recognized as a key factor for the management of a shared resource) has decreased, but other regulation systems exist, including threats of sorcery, moral judgments and the moral obligation to share fish.

\section{BIBLIOGRAPHY}

Abe'ele Mbanzo'o P. 2001 - La pêche traditionnelle badjoué : appropriation d'une ressource mobile. In Delvingt W. (Ed.) La forêt des hommes : terroirs villageois en forêt tropicale africaine. Gembloux, Les Presses Agronomiques de Gembloux : 43-64.

Agence nationale de l'aviation civile, Brazzaville, Congo Republic, personal communication, 2015 Béné C., Neiland A., Jolley T., Ovie S., Sule O., Ladu B., Mindjimba K., Belal E., Tiotsop F., Baba M., Dara L., Zakara A., \& Quensiere J. 2003 - Natural-resource institutions and property rights in inland African fisheries: The case of the Lake Chad Basin region. International Journal of Social Economics $30: 275-301$.

Béné C., Steel E., Luadia B.K., \& Gordon A. 2009 - Fish as the "bank in the water" - Evidence from chronic-poor communities in Congo. Food Policy $34: 108-118$.

Bernault F. 2005 - Magie, sorcellerie et politique au Gabon et au Congo-Brazzaville. In Mve Mbekale M. (Ed.) Démocratie et mutations culturelles en Afrique noire. Paris, L'Harmattan : 21-39.

Campbell D. 2005 - The Congo River Basin. In Fraser L.H. \& Keddy P.A. (Ed.) The world's largest wetlands: ecology and conservation. Cambridge, Cambridge University Press : 149-165. 
Carrière S. 2003 - Les orphelins de la forêt: pratiques paysannes et écologie forestière (Ntumu, SudCameroun). Paris, IRD Éditions, $376 \mathrm{p}$.

Centre National de la Statistique et des Études Économiques (CNSEE) 2007 - Recensement général de la population et de l'habitation. Brazzaville, Ministère du Plan et de l'Aménagement du Territoire, $23 \mathrm{p}$.

Chapman L.J. \& Chapman C. 2001 - Fishes of African rain forests. In Weber W., White L.J.T., Vedder A. \& Naughton-Treves L. (Ed.) African rain forest ecology and conservation: An interdisciplinary perspective. New Haven, CT, Yale University Press : 263-290.

Coppet D. de 1981 - The life-giving death. In Humphreys S. \& King H. (Ed.) Mortality and immortality. The anthropology and archaeology of death. New York, Academic Press : 75-204.

Descola P. 2011 - L'écologie des autres. L'anthropologie et la question de la nature. Paris, Quae, 110 p.

Dounias E. 2011 - La pêche chez les peuples forestiers d'Afrique centrale. In Paugy D., Lévêque C. \& Mouas I. (Ed.) Poissons d'Afrique et peuples de l'eau. Marseille: IRD Éditions : 209-231.

Erickson C.L. 2000 - An artificial landscape-scale fishery in the Bolivian Amazon. Nature 408 : 190-193.

Fay C. 1989a - Sacrifices, prix du sang, "eau du maître" : fondation des territoires de pêche dans le delta central du Niger (Mali). Cahiers des Sciences Humaines 25 : 159-176.

Fay C. 1989 b - Systèmes halieutiques et espaces de pouvoirs : transformation des droits et des pratiques de pêche dans le delta central du Niger (Mali) 1920-1980. Cahiers des Sciences Humaines $25: 213-236$.

Fergusson R. 2010 - Nile Crocodile Crocodylus niloticus. In Manolis S.C. \& Stevenson C. (Ed.) Crocodiles. Status survey and conservation action plan. $3 \mathrm{~d}$ ed. Darwin, Crocodile Specialist Group : 84-89.

Gabriel O., Lange K., Dahm E. \& Wendt T. (Ed.) 2008 - Fish catching methods of the world. 4th ed. Oxford, Blackwell Publishing Ltd, 536 p.

Gami N. 2002 - Étude de l'aménagement forestier exemplaire en Afrique centrale : le sanctuaire des gorilles de Lossi, République du Congo. Rome, FAO, 36 p.

Graaf G. de, Bartley D., Jorgensen J. \& Marmulla G. 2015 - The scale of inland fisheries, can we do better? Alternative approaches for assessment. Fisheries Management and Ecology 22 : 64-70.

Harms R. 1989 - Fishing and systems of production : The precolonial Nunu of the middle Zaïre. Cahiers des Sciences Humaines 25 : 147-158.

Harms R. 1999 - Games against nature: An eco-cultural history of the Nunu of equatorial Africa. Cambridge, Cambridge University Press, 276 p.

Henry C. \& Kadya Tall E. 2008 - La sorcellerie envers et contre tous. Cahiers d'Études Africaines $189-190: 11-34$.

Ingold T. 2000 - The perception of the environment: essays on livelihood, dwelling and skill. London \& New York, Routledge, $465 \mathrm{p}$.

Laraque A. \& Maziezoula B. 1995 - Banque de données hydrologiques des affluents congolais du fleuve Congo-Zaïre et informations physiographiques. Programme PEGI-GBF volet CONGO. Montpellier, ORSTOM, et Brazzaville, DGRST Congolaise.

Laraque A. \& Olivry J. 1996 - Évolution de l'hydrologie du Congo-Zaïre et de ses affluents rive droite et dynamique des transports solides et dissous. IAHS Publications 238 : 271-288. 
Leenhardt M. 1971 - Do kamo. La personne et le mythe dans le monde mélanésien. Paris, Gallimard, 322 p.

Lévêque C. 2006 - Réponses aux conditions extrêmes. In Lévêque C. \& Paugy D. (Ed.) Les poissons des eaux continentales africaines: diversité, écologie, utilisation par l'homme. Paris, IRD Éditions :

217-225.

Lévêque C. \& Paugy D. 2006 - Caractéristiques générales de la faune ichtyologique. In Lévêque C. \& Paugy D. (Ed.) Les poissons des eaux continentales africaines: diversité, écologie, utilisation par l'homme . Paris, IRD Éditions : 45-59.

Levy-Bruhl L. 1963 - Le surnaturel et la nature dans la mentalité primitive, nouvelle édition. Paris, Les Presses universitaires de France, $526 \mathrm{p}$.

Manzi M. \& Coomes O.T. 2010 - Cormorant fishing in southwestern China: a traditional fishery under siege. Geographical Review $92:$ 597-603.

Ndinga Mbo A. 2006 - Introduction à l'histoire des migrations au Congo-Brazzaville. Les Ngala dans la cuvette congolaise XVII ${ }^{e}$-XIX ${ }^{e}$ siècle. Paris, L'Harmattan, 295 p.

Neiland A.E., Weeks J., Madakan S.P. \& Ladu B.M.B. 2000 - Inland fisheries of north east Nigeria including the Upper River Benue, Lake Chad and the Nguru-Gashua wetlands: II. Fisheries management at village level. Fisheries Research $48: 245-261$.

Oishi T. \& Hagiwara M. 2015 - A preliminary report on the distribution of freshwater fish of the Congo River: based on the observation of local markets in Brazzaville, Republic of the Congo. African Study Monographs. Supplementary Issue 51 : 93-105.

Ostrom E. 1990 - Governing the Commons: The Evolution of Institutions for Collective Actions. Cambridge, Cambridge University Press, 280 p.

Pagezy H. 1989 - Alimentation et saisonnalité dans la région du lac Tumba. In Hladik C.M., Bahuchet S. \& Garine I. de (Ed.) Se nourrir en forêt équatoriale. Paris, UNESCO/MAB : 36-42.

Pagezy H. 2006 - Le contexte magico-religieux de la pêche au lac Tumba : entre le "normal" et l'insolite. Journal des Africanistes $76:$ 44-62.

Pagezy H. \& Guagliardo V. 1992 - Rôle du surnaturel dans la gestion des ressources naturelles chez les Ntomba du Zaïre. Ecologie Humaine 10 : 69-77.

Paugy D., Levêque C. \& Mouas I. (Ed.) 2015 - Poissons d'Afrique et peuples de l'eau. Marseille, IRD Éditions, $320 \mathrm{p}$.

Plancke C. 2011 - The spirit's wish: possession trance and female power among the Punu of Congo-Brazzaville. Journal of Religion in Africa 41 : 366-395.

Reo N.J. \& Whyte K.P. 2012 - Hunting and morality as elements of traditional ecological knowledge. Human Ecology 40 : 15-27.

Riley J. \& Huchzermeyer F.W. 1999 - African dwarf crocodiles in the Likouala swamp forests of the Congo basin: habitat, density, and nesting. Copeia : 313-320.

Sarch M.T. 2001 - Fishing and Farming at Lake Chad: Institutions for Access to Natural resources. Journal of Environmental Management 62 : 185-199.

Sautter G. 1962 - La cuvette congolaise : monographie régionale des bassins de la Likouala-Mossaka, de l'Alima et de la Nkéni. Paris, Ministère de la coopération, 70 p.

Schlager E. \& Ostrom E. 1992 - Property-rights regimes and natural resources: a conceptual analysis. Land economics $68: 249-262$. 
Shepard G.H. 2014 - Hunting in Amazonia. In Selin H. (Ed.) Encyclopaedia of the History of Science, Technology, and Medicine in Non-Western Cultures. Dordrecht, Springer Netherlands : 1-7.

Smith L., Khoa S. \& Lorenzen K. 2005 - Livelihood functions of inland fisheries: policy implications in developing countries. Water Policy $7: 359-383$.

Strathern M. 1988 - The gender of the gift. Problems with women and problems with society in Melanesia. Berkeley, Los Angeles, London, University of California Press, 437 p.

Thomas D.H.L. 1996 - Fisheries tenure in an African floodplain village and the implications for management. Human Ecology 24 : 287-313.

Toko I., Fiogbe E.D., Koukpode B. \& Kestemont P. 2007 - Rearing of African catfish (Clarias gariepinus) and vundu catfish (Heterobranchus longifilis) in traditional fish ponds (whedos): effect of stocking density on growth, production and body composition. Aquaculture 262:65-72.

Trusler S. \& Johnson L.M. 2008 - "Berry patch" as a kind of place-the ethnoecology of black huckleberry in northwestern Canada. Human Ecology 36 : 553-568.

Van Leynseele P. 1979 - Les transformations des systèmes de production et d'échanges de populations ripuaires du Haut-Zaïre. African Economic History 7 : 117-129.

Vennetier P. 1966 - Géographie du Congo-Brazzaville. Paris, Gauthier-Villars, 174 p.

Wagner R. 1991 - The fractal person. In Godelier M. \& Strathern M. (Ed.) Big Men and Great Men. Personifications of power in Melanesia. Cambridge (UK), Cambridge University Press : 159-167.

Waitkuwait W. 1989 - Present knowledge on the West African slender-snouted crocodile, Crocodylus cataphractus Cuvier 1824 and the West African dwarf crocodile Osteolaemus tetraspis Cope 1861. In Crocodiles. Their ecology, management, and conservation. Gland, IUCN Publication new series : 260-275.

Welcomme, R.L. 1975 - The fisheries ecology of African floodplains. Rome, FAO, CIFA Technical Paper, $51 \mathrm{p}$.

Welcomme R.L., Cowx I.G., Coates D., Béné C., Funge-Smith S., Halls A. \& Lorenzen K. 2010 - Inland capture fisheries. Philosophical Transactions of the Royal Society B: Biological Sciences $365: 2881-2896$.

Yengo P. 2008 - Le monde à l'envers. Enfance et kindoki ou les ruses de la raison sorcière dans le bassin du Congo. Cahiers d'Études Africaines 189-190 : 297-323.

\section{NOTES}

1. The spellings of the names of ethnic groups given in this manuscript are those most frequently encountered in the literature.

2. All vernacular terms in this manuscript are given in the Likouba language (Group C27 of the Guthrie Classification of Bantu languages) and in the singular form. For the plural form, see the lexicon in Annex. This Annex also gives the complete scientific name of each species cited in the text. The Likouba vernacular terms are written phonetically using the International Phonetic Alphabet, without mention of the tonal accents.

3. kopopa literally means "to scoop". This verb is also used when people scoop the water out of their canoe.

4. With their authorization, informants are quoted using their real name. All interviews in this manuscript were conducted in Mossaka between April and December 2015. All quotations in this manuscript are the authors' translations from French. 
5. CFA Franc (XAF in ISO 4217 code) is the currency used in the Franc zone of Central Africa. $100,000 \mathrm{XAF}$ is equivalent to 152.5 Euro. Depending on the market price (which fluctuates greatly across seasons), it corresponds roughly to an amount of 25 to $30 \mathrm{~kg}$ of smoked fish.

6. Ponds are often situated in inundated forests. In the region of Mossaka, forests are periodically or permanently aquatic habitats.

7. Water spirits can be of either of feminine or masculine gender (Pagezy 2006). In this study, we do not specify the sex of the bweta and will use the pronoun « he » to refer to any spirit.

8. The person interviewed refers here to a period preceding the filling of the city of Mossaka and of the ekembongo River with sand derived from sand-dredging in the Congo River. This process began in 1965, and the last phase of dredging (still ongoing) began in 2014.

9. Other fisheries requiring particular negotiations with the spirits included dam fishing and fishing using ichthyotoxic plants. Nowadays, these collective fishing methods are also declining in the region of Mossaka.

10. In the Likouba cosmogony, the water spirit appears in the shape of the crocodile to manifest itself to a fisherman who has disrespected the contract. The vision of $C$. niloticus is a warning sign for a fisherman who will interpret it as a threat.

11. The Likouba use the verb «to eat " (kolia) to designate this spirit sacrifice, or in talking about acts of sorcery that lead to the death of the victim.

12. The rapid urbanization and population growth in Congo Republic in the second half of the 20th century resulted in a growing demand in the capital for freshwater fish, which is the major source of proteins.

13. This change brings to mind the notion of «dividuality », which describes how a person can be composite or fractal, and a plural entity comprising relationships (Leenhardt 1971, Coppet 1981, Strathern 1988, Wagner 1991). By losing their responsibility as mediators with spirits, managers of conflicts, and distributors of common resources within the lineage, lineage heads are losing their property of «dividuality». They are more and more bounded individuals in relation to society.

\section{ABSTRACTS}

In the Congo basin, fishing activities are a major source of protein and of income for many households. Fishermen combine a broad range of fishing methods adapted to the seasonality of the floodplain and the particular features of its habitats. Pond fishing is a collective fishing method that consists in emptying pools still flooded during the low-water season in the otherwise dry floodplain in order to capture the fish that have sought shelter there. This practice is widespread in central Africa but has rarely been described in detail. Studies often depict this activity as quite simple and practiced by groups of women only. Our study, conducted in the region of Mossaka, in Congo Republic, reveals another reality. We found that pond fishing engages dozens of men, women and children working together and that this activity is based on a range of skills and know-how. Pond fishing is one of the most productive and socially valued fishing methods in the region. Like the technical dimensions of pond fishing, its social and symbolic dimensions are also little described in literature on the subject. Because pond ownership is a source of income and prestige, pond fishing crystallizes social competition. Yet, the collective nature of this fishery enhances alliances and social networks. Pond fishing is also 
rooted in beliefs about multiple relationships between humans, fish, crocodiles, and supernatural forces inhabiting the ponds. Pond fishing, like collective fishing as a whole, has been in decline for the last 50 years. Fishermen nowadays engage preferentially in individual techniques. We examine whether these individual fishing methods allow maintenance of the social and cultural functions of inland fisheries.

Dans le bassin du Congo, la pêche constitue une source majeure de protéines et de revenus pour de nombreux foyers. Les pêcheurs combinent une grande diversité de techniques de pêche, adaptées aux facteurs hydrologiques saisonniers et aux milieux prospectés. La pêche aux étangs est une technique de pêche collective qui consiste à écoper des mares d'eau dans la plaine d'inondation durant la saison des basses eaux, de manière à capturer les poissons qui s'y étaient réfugiés. Cette pratique, largement répandue en Afrique centrale, a rarement été décrite en détail. Les études dépeignent souvent cette activité comme une pêche relativement simple et exclusivement féminine. Notre étude, réalisée dans la région de Mossaka en République du Congo, montre une autre réalité. Dans cette région, la pêche aux étangs est pratiquée par plusieurs dizaines d'hommes, femmes et enfants travaillant ensemble, et nécessite de nombreux savoirs et savoir-faire. La pêche aux étangs est une des pêches les plus productives et les plus valorisées de cette région. Tout comme les dimensions techniques, les aspects sociaux et symboliques de la pêche aux étangs ont peu été décrits dans la littérature. Source de prestige et de richesse, la pêche aux étangs cristallise des rapports de compétition. Cependant, la nature collective de cette pêche favorise le renforcement de relations sociales d'alliances. Cette pêche est également ancrée dans des croyances mettant en jeu de nombreuses relations entre les pêcheurs, les poissons, les crocodiles et les génies habitant les étangs. La pêche aux étangs, à l'image des autres pêches collectives, est en déclin. Les pêcheurs favorisent aujourd'hui des techniques de pêche individuelles. Nous examinons si ces pratiques individuelles permettent de maintenir les fonctions sociales et culturelles des activités de pêche.

\title{
INDEX
}

Population Likouba (République du Congo)

Mots-clés: pêche, plaine d'inondation, pêche continentale, pêche aux étangs, savoirs locaux, organisation sociale, esprits des eaux, Bassin du Congo, Cuvette congolaise, Mossaka

Keywords: fishing, floodplain, inland fishery, pond fishing, local knowledge, social organization, water spirits, Congo basin, Congolese cuvette, Mossaka, Likouba

\section{AUTHORS}

\section{MARION COMPTOUR}

\author{
SOPHIE CAILLON
}

DOYLE MCKEY 